\title{
Cystic fibrosis and the month of birth
}

\author{
T J DAVID, GILlian A ELSTOW, J H BAUMER, AND C MARY EVANS
}

From the Department of Child Health, University of Manchester, Manchester, and the Department of Child Health, University of Bristol, Bristol

SUMMARY A bimodal birth distribution and seasonal trend has been previously reported in cystic fibrosis. The present study of 412 cases in Manchester and Bristol does not confirm the presence of a seasonal trend or any cyclic variation, and in general the trends in the present study are the reverse of those in the previous reports.

It is difficult to understand why an autosomal recessive disease should show a seasonal trend. Nevertheless, in cystic fibrosis this has been suggested several times. ${ }^{1-4}$ The most recent study ${ }^{2}$ has reported a peak of cystic fibrosis births in February and August, the birth frequencies being bimodally distributed.

Cystic fibrosis appears to be the first single gene disorder for which a seasonal birth pattern has been described, and in this study we have sought to verify this curious finding.

\section{Material and methods}

Only proved cases of cystic fibrosis were included, using the criteria suggested by Anderson and Goodchild. ${ }^{5}$ A few atypical cases, such as children with normal sweat sodium levels, were excluded.

Cases seen at Booth Hall Children's Hospital, Manchester, the Royal Manchester Children's Hospital, and the Bristol Royal Hospital for Sick Children were studied. Ascertainment was by (1) hospital diagnostic indices; (2) necropsy diagnostic indices; and (3) bacteriology laboratory records. We attempted to obtain complete ascertainment, though for early years this was impossible. Cases who died were included.

\section{Results}

We traced 412 patients. The results for the year of birth are shown in table 1 and those for the month of birth in table 2. A comparison of winter and summer births is given in table 3.

On the null hypothesis that the same number of cases should be born in each calendar month, $\chi_{11}^{2}=17 \cdot 50$ (not significant).

Received for publication 9 September 1980
On the null hypothesis that the proportion of cases born in each calendar month should be the same as the distribution of live births by month in England and Wales over the period of study, adjusted in proportion to the number of cases in each year, $\chi_{1.1}^{2}=$ $17 \cdot 8$ (not significant).

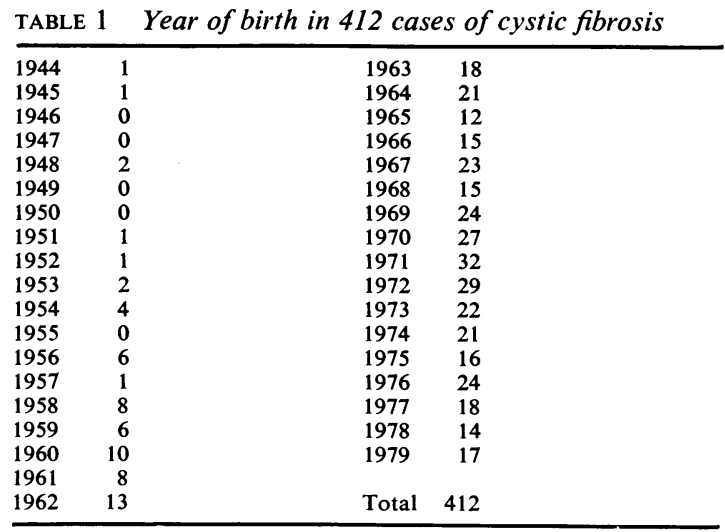

TABLE 2 Cystic fibrosis: month of birth

\begin{tabular}{lclll}
\hline & Holland ${ }^{1}$ & $\begin{array}{l}\text { Melbourne, } \\
\text { Australia }\end{array}$ & $\begin{array}{l}\text { England and } \\
\text { Wales }\end{array}$ & $\begin{array}{l}\text { Manchester and } \\
\text { Bristol } \\
\text { present series) }\end{array}$ \\
\hline January & 30 & 22 & 75 & 41 \\
February & 32 & 24 & 78 & 27 \\
March & 34 & 26 & 94 & 46 \\
April & 21 & 33 & 82 & 29 \\
May & 28 & 36 & 77 & 28 \\
June & 26 & 21 & 73 & 33 \\
July & 21 & 30 & 77 & 34 \\
August & 23 & 33 & 79 & 29 \\
September & 26 & 30 & 80 & 38 \\
October & 25 & 37 & 78 & 23 \\
November & 19 & 28 & 65 & 40 \\
December & 27 & 22 & 65 & 44 \\
Total & 312 & 342 & 923 & 412 \\
Total $\div$ 12 & 26 & $28 \cdot 5$ & $76 \cdot 9$ & $34 \cdot 3$ \\
\hline
\end{tabular}


TABLE 3 Cystic fibrosis: winter vs summer births

\begin{tabular}{lcccc}
\hline & Holland ${ }^{1}$ & $\begin{array}{l}\text { Melbourne, England } \\
\text { Australia }\end{array}$ & $\begin{array}{l}\text { Manchester } \\
\text { and Wales }\end{array}$ & $\begin{array}{l}\text { Mand Bristol } \\
\text { (present } \\
\text { series) }\end{array}$ \\
\hline $\begin{array}{l}\text { Winter births } \\
\text { January-March }\end{array}$ \\
$\begin{array}{l}\text { October-December } \\
\text { Summer births } \\
\text { April-September } \\
\text { Ratio }\end{array}$ & 167 & 159 & 455 & 221 \\
\hline
\end{tabular}

There was a small excess of winter births (221 to 191) which was not statistically significant $\left(\chi^{2}\right.$ values were calculated for deviations from the distribution that would be expected if there were no seasonal variation).

\section{Discussion}

We have been unable to confirm the presence of a seasonal trend in the births of persons with cystic fibrosis. Nor have we found a peak of births in February and August. Indeed, the monthly trends of the present study are in the reverse direction to those in the previous study ${ }^{2}$ in 9 out of 12 months. Furthermore, no cyclical variation is evident from our data, and any consistency in the higher than average figures for births in January to March and September to December is considerably reduced by two very low figures for February and October.

Other series have been collected in different ways, and one series ${ }^{2}$ comprised only deaths from cystic fibrosis. Whether fatal cases of cystic fibrosis can be regarded as representative of the total population of patients with this disease must be questionable. It seems most likely that the previous results were the result of sampling variation or chance. In one other study $^{6}$ no seasonal variation was found, but this has been discounted ${ }^{4}$ on the grounds that the study was made before sweat tests had been introduced, and by implication, therefore, that the series included cases of other disorders. In another previous study, ${ }^{4}$ it was only when the monthly figures for births of unaffected sibs were added to the figures for births of cases of cystic fibrosis that the modes agreed with the previously reported Dutch figures. ${ }^{1}$

Finally, a small excess of winter births was noted in this series as in the Dutch study, ${ }^{1}$ though the opposite trend was present in the Australian ${ }^{4}$ and previous British ${ }^{2}$ series.

We are grateful to the many paediatricians who kindly provided access to their records, and to $\mathrm{Dr}$ R F Williams, Dr V Schwarz, and Mrs V A Smith for their help. Mrs C Webb kindly typed the manuscript

\section{References}

1 Ten Kate LP. Cystic fibrosis in the Netherlands. Int $J$ Epidemiol 1977;6:23-34.

2 Brackenridge CJ. Bimodal month of birth distribution in cystic fibrosis. Am J Med Genet 1980;5:295-301.

3 Brackenridge CJ. Characteristics of birth in each cycle of the bimodal monthly distribution in cystic fibrosis. $\mathrm{Am}$ J Med Genet 1980;5:303-7.

4 Brackenridge CJ. The seasonal variation of births of offspring from couples heterozygous for cystic fibrosis. Ann Hum Genet 1978;42:197-201.

5 Anderson CM, Goodchild MC. Cystic fibrosis. Manual of diagnosis and management. Oxford: Blackwell, 1976.

6 Lowe CV, May CD, Reed SC. Fibrosis of the pancreas in infants and children. Am J Dis Child 1949;78:349-74.

Requests for reprints to $\mathrm{Dr} \mathrm{T} J$ David, Booth Hall Children's Hospital, Charlestown Road, Blackley, Manchester M9 2AA. 